\title{
The Phaseolus vulgaris ZIP gene family: identification, characterization, mapping, and gene expression
}

\author{
Carolina Astudillo ${ }^{1}$, Andrea C. Fernandez ${ }^{1}$, Matthew W. Blair ${ }^{2}$ and Karen A. Cichy ${ }^{1,3 *}$ \\ 1 Plant Soil and Microbial Sciences Department, Michigan State University, East Lansing, MI, USA \\ ${ }^{2}$ Department of Plant Breeding and Genetics, Cornell University, Ithaca, NY, USA \\ ${ }^{3}$ Plant Soil and Microbial Sciences Department, USDA-ARS Sugarbeet and Bean Research Unit, Michigan State University, East Lansing, MI, USA
}

\section{Edited by:}

Michael A. Grusak, USDA-ARS

Children's Nutrition Research

Center, USA

\section{Reviewed by:}

Ana-Flor Lopez-Millan, Estacion Experimental de Aula Dei-Consejo

Superior de Investigaciones

Cientificas, Spain

Vasileios Fotopoulos, Cyprus

University of Technology, Cyprus

\section{*Correspondence:}

Karen A. Cichy, Plant Soil and Microbial Sciences Department, USDA-ARS Sugarbeet and Bean Research Unit, Michigan State University, 1066 Bogue St., East Lansing, MI 48824, USA

e-mail: karen.cichy@ars.usda.gov
Zinc is an essential mineral for humans and plants and is involved in many physiological and biochemical processes. In humans, $\mathrm{Zn}$ deficiency has been associated with retarded growth and reduction of immune response. In plants, $\mathrm{Zn}$ is an essential component of more than 300 enzymes including RNA polymerase, alkaline phosphatase, alcohol dehydrogenase, $\mathrm{Cu} / \mathrm{Zn}$ superoxidase dismutase, and carbonic anhydrase. The accumulation of $\mathrm{Zn}$ in plants involves many genes and characterization of the role of these genes will be useful in biofortification. Here we report the identification and phlyogenetic and sequence characterization of the 23 members of the ZIP (ZRT, IRT like protein) family of metal transporters and three transcription factors of the bZIP family in Phaseolus vulgaris $\mathrm{L}$. Expression patterns of seven of these genes were characterized in two bean genotypes (G19833 and DOR364) under two Zn treatments. Tissue analyzed included roots and leaves at vegetative and flowering stages, and pods at 20 days after flowering. Four of the genes, PVZIP12, PVZIP13, PVZIP16, and PV bZIP1, showed differential expression based on tissue, Zn treatment, and/or genotype. PVZIP12 and PVZIP13 were both more highly expressed in G19833 than DOR364. PVZIP12 was most highly expressed in vegetative leaves under the Zn (-) treatment. PVZIP16 was highly expressed in leaf tissue, especially leaf tissue at flowering stage grown in the $\mathrm{Zn}(-)$ treatment. PV bZIP1 was most highly expressed in leaf and pod tissue. The 23 PVZIP genes and three bZIP genes were mapped on the DOR364 × G19833 linkage map. PVZIP12, PVZIP13, and PVZIP18, PV bZIP2, and PV bZIP3 were located near QTLs for Zn accumulation in the seed. Based on the expression and mapping results, PVZIP12 is a good candidate gene for increasing seed $Z n$ concentration and increase understanding of the role of ZIP genes in metal uptake, distribution, and accumulation of zinc in P. vulgaris.

Keywords: biofortification, Phaseolus vulgaris, OTL mapping, gene expression, zinc transporter

\section{INTRODUCTION}

Dry beans (Phaseolus vulgaris $\mathrm{L}$ ) are the most highly consumed whole food legume in the world. Beans are a food security crop for small farmers and urban poor in many African and Latin American countries (Siddiq and Uebersax, 2012). In contrast to many other staple crops, beans are rich in a variety of nutrients, including protein, fiber, folate, and minerals (Juliano, 1999). Beans are also a good source of dietary iron and zinc. According to the USDA Nutrient Database, a $100 \mathrm{~g}$ of cooked beans provides an average of $2 \mathrm{mg} F e$ and $1 \mathrm{mg} \mathrm{Zn}$ and the Estimated Average Requirement for Fe ranges from 3 to $23 \mathrm{mg}$ per day and 2.5$10.9 \mathrm{mg}$ per day per $\mathrm{Zn}$ depending on age and gender (Ahuja et al., 2012). Meeting the Fe and $\mathrm{Zn}$ dietary requirements is a challenge for many people. An estimated two billion people suffer from iron deficiency, which is a major cause of anemia (Rastogi and Mathers, 2002; Balarajan et al., 2011). Zinc deficiency is also widespread, with an estimated $48 \%$ of humans at risk, especially populations consuming vegetarian diets rich in unrefined cereals (Sandstead, 1991). In humans, Zn deficiency can be expressed through diverse symptoms including reduced immune function, fetal brain cell development and child's growth, reproductive, and cognitive development (Hambidge, 2000). Biofortification of staple foods, including dry beans, with $\mathrm{Fe}$ and $\mathrm{Zn}$ is one agricultural based approach being developed and applied to combat micronutrient malnutrition (Bouis et al., 2011). While average dry bean $\mathrm{Fe}$ and $\mathrm{Zn}$ levels are $55 \mathrm{mg} \mathrm{kg}^{-1}$ and $34 \mathrm{mg} \mathrm{kg}^{-1}$ respectively, three-fold genotypic variation in both Fe and Zn levels exist within the species (Blair et al., 2009 and Islam et al., 2002).

This existing variation makes breeding common beans a viable biofortification approach. Significant progress has been achieved in Fe biofortification of beans through conventional breeding as illustrated in the recent release of five high Fe bean varieties in Rwanda (Saltzman et al., 2013). Zinc biofortification has lagged behind that of Fe-biofortification perhaps because of lower quantities of $\mathrm{Zn}$ in the seeds but also perhaps less incentive because of the difficulty in assessing $\mathrm{Zn}$ nutritional status in humans. While there are biomarkers to asses Fe deficiency readily in humans, 
no such biomarkers are yet available for $\mathrm{Zn}$, although recently a potential biomarker (dematin) has been identified (Ryu et al., 2012).

In addition to relying solely on phenotypic selection to increase seed Fe and $\mathrm{Zn}$ levels, there has been an effort to understand the genetic control of seed $\mathrm{Zn}$ and Fe accumulation. Since 2009, at least five QTL studies have been published for seed micronutrient levels. In total, 38 QTLs were associated with zinc accumulation, explaining $15-40 \%$ of the variability. These studies have been in inter gene pool populations (Blair et al., 2009, 2010a,b), Andean populations (Cichy et al., 2009; Blair et al., 2011) and Mesoamerican populations (Blair et al., 2010a). QTL studies have yet to be applied to marker assisted selection. There has also been limited effort in identifying genes underlying QTL for $\mathrm{Fe}$ and $\mathrm{Zn}$. Discovery of genes involved in increased seed Fe and $\mathrm{Zn}$ levels would be useful for biofortification efforts in beans and possibly also as targets for transgenic biofortification approach in other crops.

The Zrt and Irt-like protein (ZIP) family is well characterized for its role in $\mathrm{Zn}$ transport and to a lesser extent it role in Fe transport (Eide et al., 1996). The ZIP family is well conserved among bacteria, fungi, protozoa, animals, and plants (Grotz et al., 1998; Chen et al., 2008). ZIP proteins are predicted to have eight transmembrane domains with a histidine motif which may be part of an intramembranous heavy metal binding site that plays a role in the transport pathway for the minerals that are transferred (Eng et al., 1998). ZIP transporters have been implicated in Zn uptake, transport of $\mathrm{Zn}$ in leaves and translocation to seeds, embryo, endosperm, and seed coat (Waters and Sankaran, 2011). Previous information on the role of ZIP genes in $\mathrm{Zn}$ movement throughout the plant come from expression analysis, yeast complementation and $\mathrm{Zn}$ hyper accumulator mutants. In A. thaliana 15 members have been identified and characterized, revealing a wide variety of localization and function (Milner et al., 2012). AtZIPs have been detected mainly in the roots, shoots (Milner et al., 2012). In rice, 17 ZIP coding sequences (CDS) were identified. They have been evaluated in roots, shoots, and panicles of efficient and inefficient genotypes (Grotz et al., 1998; Guerinot, 2000; Connolly et al., 2002; Weber et al., 2004; Chen et al., 2008; Shanmugam et al., 2011; Milner et al., 2012). In Medicago truncatula, six genes were identified in roots and leaves which were upregulated under $\mathrm{Zn}$ deficiency and three of them restored yeast growth on $\mathrm{Zn}$-limited media (Lopez-Millan et al., 2004). In Glycine max, GmZIP1 has been detected in nodules and was highly selective for $\mathrm{Zn}$ in a functional complement in yeast (Moreau et al., 2001). In Vitis vinifera, $V v Z I P 3$ was expressed in developing flowers and its expression was correlated with high $\mathrm{Zn}$ accumulation in this tissue (GainzaCortes et al., 2012 and Afoufa-Bastien et al., 2010). Analysis of this family in different species demonstrates the importance of these genes in $\mathrm{Zn}$ transport.

Another important gene family related with $\mathrm{Zn}$ transport is the bZIP family. This family has been well characterized in Arabidopsis with 75 members divided in 10 groups based on conserved motifs that reflect functional similarities (Jakoby et al., 2002). Group F includes bZIP19, bZIP23, and bZIP24. These transcription factors contain a DNA binding domain, a leucine zipper dimerization motif and histidine-rich motif which are essential for responding to low $\mathrm{Zn}$ supply in Arabidopsis (Assuncao et al., 2003; Assunção et al., 2010).

With the recent release of the $P$. vulgaris genome sequence (Phaseolus vulgaris v1.0, DOE-JGI and USDA-NIFA, http://www. phytozome.net/commonbean), it is possible to identify candidate genes for seed Fe and $\mathrm{Zn}$ levels. Characterization of genes related to $\mathrm{Zn}$ homeostasis in $P$. vulgaris will provide useful information on specific target genes in the biofortification breeding effort. This research has identified and characterized of 23 members of the PvZIP gene family. Three members of a second family of genes, bZIP transcription factors, were also characterized similarly. The relative expression of genes from both the ZIP and bZIP families was characterized in various tissues and stages of development in two P. vulgaris genotypes, DOR 364 and G19833 grown under two $\mathrm{Zn}$ treatments. Selected ZIP and bZIP genes were also located on a linkage map overlaid with QTL locations for $\mathrm{Zn}$ accumulation in seed.

\section{MATERIALS AND METHODS PLANT MATERIAL AND PHENOTYPIC DATA}

Two bean genotypes were evaluated in this study, DOR364, a small seeded, high yielding improved cultivar from the Middle American genepool and G19833, a large seeded landrace from the Andean genepool known for its tolerance to low P soils (Beebe et al., 2006). These genotypes also exhibit contrasting seed mineral levels as shown in field trials in Darien, Colombia. DOR364 had $49 \mathrm{mg} \mathrm{kg}^{-1} \mathrm{Fe}$ while G19833 had $75.5 \mathrm{mg} \mathrm{kg}^{-1}$, and DOR364 had $21.7 \mathrm{mg} \mathrm{kg}^{-1} \mathrm{Zn}$ while G19833 had $29.9 \mathrm{mg} \mathrm{kg}^{-1}$ (Blair et al., 2009). DOR364 and G19833 were specifically chosen for this study because valuable genetic information exists for the lines. A recombinant inbred line (RIL) between these parents was developed by single seed descent at the International Center for Tropical Agriculture (CIAT), Colombia. It consists of 87 individuals and has a linkage map of 499 single copy markers with a coverage of $2306 \mathrm{cM}$ (Galeano et al., 2011). This population has been used by different research groups for map saturation and QTL identification associated to biotic and abiotic traits (Blair et al., 2009) and QTL positions for seed minerals (Blair et al., 2003, 2009; Beebe et al., 2006; Galeano et al., 2011).

\section{IDENTIFICATION OF Pv ZIP AND Pv bZIP GENES AND PHYLOGENETIC ANALYSIS}

ZIP genes in P. vulgaris were identified using the sequences of 18 Arabidopsis thaliana ZIP genes (http://www.arabidopsis.org/). The program tBlastn was used to compare the Arabidopsis ZIP genes against the bean genome (Phaseolus vulgaris v1.0, DOE-JGI and USDA-NIFA, http://www.phytozome.net/commonbean). These sequence data were produced by the US Department of Energy Joint Genome Institute. Conserved domains in each predicted transcript was verified using Pfam 26.0 protein database (http://pfam.sanger.ac.uk/) to confirm the reliability of the match with the ZIP family. The CDS for each gene was aligned with genomic DNA sequence to confirm splice signals in boundaries between introns and exons. The P. vulgaris ZIP genes were assigned unique names from $P v Z I P 1$ to $P v Z I P 19$ and PvIRT1 to PvIRT4. These names do not relate to naming of ZIP genes in others species. Since this gene family characterization 
is based on an incomplete genome sequence, the existence of additional ZIP genes in the bean genome is a possibility.

Three $P v$ bZIP genes were identified in the $P$. vulgaris genome based on sequences of $b Z I P 19, b Z I P 23$, and $b Z I P 24$ reported by Assunção et al. (2010) in Arabidopsis. Identification of the new bZIP genes was based on the homology with the Basic Leucine Zipper Domain (bZIP domain).

Sequence alignments, phylogenetic analysis, tree estimation using bootstrapping and graphs of each gene were performed using ClustalW (Larkin et al., 2007) using the program Geneious ${ }^{\circledR}$ 6.0.3, created by Biomatters (build 2012-11-06 10:52).

\section{In silico MAPPING OF Pv ZIP AND Pv bZIP GENES}

Each of the 23 putative ZIP transport protein genes and 3 putative bZIP transcription factor genes were mapped in silico to a location on the DOR364 x G19833 linkage map based on sequence homology with the P. vulgaris genome. This alignment was conducted with an MS Excel based program MapSynteny (Fernandez et al., 2011).

\section{GENETIC MAPPING OF SELECT MEMBERS OF THE PvZIP AND Pv bZIP FAMILY GENES}

Five ZIP genes were also mapped genetically in the DOR364 $\times$ G19833 population. These five genes were chosen for genetic mapping based on their location near QTLs for seed Fe and Zn concentration on chromosomes 1, 3, 6, and 8 (Blair et al., 2009). The ZIP genes located in silico in these regions were mapped genetically in the full set of RILs of the DOR364 × G19833 population. These include PvZIP2, PvZIP6, PvZIP8, PvZIP13, and $P v I R T 3$. Primers were designed to flank ZIP gene intron sequence (Table 1). PCR was conducted on DOR364 and G19833 as a first step to test for polymorphisms. The PCR mix contained $2.0 \mathrm{mM}$ $\mathrm{Mg}, 0.2 \mu \mathrm{M}$ dNTPs, and $0.3 \mu \mathrm{M}$ of each primer. PCR reactions were carried out for $3 \mathrm{~min}$ at $95^{\circ} \mathrm{C}$, followed by 35 cycles of $30 \mathrm{~s}$ at $95^{\circ} \mathrm{C}, 30 \mathrm{~s}$ at 55 or $60^{\circ} \mathrm{C}$ (based on the annealing temperature of each primer), and a final period of $5 \mathrm{~min}$ at $72^{\circ} \mathrm{C}$. Products were visualized on agarose gels to verify amplification and identify insertion/deletions that had potential to serve as molecular markers. To increase the possibility of finding polymorphisms for monomorphic products, the SSCP technique (from single strand conformational polymorphism) was used, which is based on detection of conformational differences of single stranded DNA fragments due mobility shifts in non-denaturing polyacrylamide gel electrophoresis (Orita et al., 1989) such as MDE acrylamide gels (MDE Gel Solution 250ML Lonza NJ, USA) as described in Galeano et al. (2009). For genetic mapping, Mapdisto software version 1.7 Beta 132 (Lorieux, 2012) was used to locate the position of the ZIP genes on the DOR364 × G19833 genetic map reported by Galeano et al. (2011). The command place locus was used to located the ZIP genes, using as criteria the highest LOD value and lowest recombination rate. The position of each ZIP gene was confirmed using the Ripple order command.

\section{OTL DATA AND ANALYSIS}

Phenotypic data for seed Fe and $\mathrm{Zn}$ concentration from Popayan and Darien Colombia in 1998 and 2003 were reported for this population in Blair et al. (2009). Additionally, seed Fe and Zn concentration from the same locations in 2006 (not previously reported) were used for QTL analysis with the linkage map reported in Galeano et al. (2011). QTL cartographer v. 2.5 (Wang et al., 2012) was used to find QTLs following the same parameters described in Blair et al. (2009).

\section{EXPRESSION ANALYSIS OF SELECT Pv ZIP AND Pv $b Z I P$ Plant growing conditions}

Seeds of DOR364 and G19833 were surface sterilized and planted in $500 \mathrm{ml}$ clay pots with 3:1 Sunshine Brand premium grade vermiculite (Sunshine Brand, TX, USA) and horticultural grade perlite (Industries, Inc., MA, USA). Half strength Hoagland solution $\left(3 \mathrm{mM} \mathrm{KNO}_{3}, 2 \mathrm{mM} \mathrm{Ca}\left(\mathrm{NO}_{3}\right)_{2} \times 4 \mathrm{H}_{2} \mathrm{O}\right.$, sequestrene DTPA $10 \% \mathrm{Fe}, 1.0 \mathrm{mM} \mathrm{MgSO}_{4} \times 7 \mathrm{H}_{2} \mathrm{O}, 23.1 \mathrm{mM} \mathrm{H} 3 \mathrm{BO} 3,0.38 \mathrm{mM}$ $\mathrm{ZnSO} 4 \times 7 \mathrm{H} 2 \mathrm{O}, 0.16 \mathrm{mM} \mathrm{CuSO} 4 \times 5 \mathrm{H} 2 \mathrm{O}, 4.6 \mathrm{mM} \mathrm{MoO} 4 \times$ $2 \mathrm{H} 2 \mathrm{O}, 1 \mathrm{M} \mathrm{KH} 2 \mathrm{PO} 4$ ( $\mathrm{pH}$ to 6.0 ) was applied to pots a rate of $400 \mathrm{ml}$ three times per week. Two Hoagland solution treatments were employed: (1) $\mathrm{Zn}(+)$ where $\mathrm{Zn}$ was added as $\mathrm{ZnSO}_{4} \times$ $7 \mathrm{H}_{2} \mathrm{O}$ and (2) $\mathrm{Zn}(-)$. A total of three pots per genotype were planted and each one was designated as a biological replicate. The experiment was arranged as a randomized complete block design. Plants were grown in a growth chamber $\left(1.86 \mathrm{~m}^{2}\right)$ with a photoperiod of $16 \mathrm{~h}$ light and $8 \mathrm{~h}$ dark and an average of temperature of $29^{\circ} \mathrm{C} / 20^{\circ} \mathrm{C}$ (day/night). For the vegetative samples, roots, and leaves were collected from the vegetative 3 stage (V3), when the third trifoliate leaf was unfolded at node 5. Leaf and

Table 1 | Primer list for gene expression analysis via RT-qPCR and genetic mapping.

\begin{tabular}{|c|c|c|c|}
\hline \multirow{2}{*}{$\begin{array}{l}\text { Gene } \\
\text { PvZIP12 }\end{array}$} & \multicolumn{2}{|c|}{ Sequence } & \multirow{2}{*}{$\begin{array}{l}\text { Approach } \\
\text { RT qPCR }\end{array}$} \\
\hline & GGGCAGAGGCAAGTGCAGGG & GGGCGTGATGGAGATGCAGGA & \\
\hline PvZIP13 & CGCGCTCTTCGATTGCCAGGT & CCACCGGCGTGTAGTGCGTA & $\mathrm{RT}$ qPCR \\
\hline PvZIP16 & TGCACGGTTGATGGCGACGG & ACGGAACTCCTTCGCCATCGT & RT qPCR \\
\hline PvIRT3 & AGAATAACACCATCCCCAAAATTA & AGTCACTATGGGAATGTCACAGAA & $\mathrm{RT}$ qPCR \\
\hline bZIP2 & ATCGGGAGAAGAAGAAGGCTCGCGC & TCCGGCCCCTTATGTCCACCAGCAA & $\mathrm{RT}$ qPCR \\
\hline bZIP3 & GCAGCAGTTCTTGAGCGTGGAGGCT & TGAAGGTGGTGTTGCCGAAACCTGCA & RT qPCR \\
\hline Pvactinll & TGCCATCCAGGCCGTTCTTTCA & GGGGACTGTGTGGCTGACACC & RT qPCR \\
\hline
\end{tabular}


root samples collected at flowering were harvested at the R2 stage when $30 \%$ of the flowers were opened. Pod samples were collected at 20 days after flowering. Plant tissue was collected in labeled sterilized tubes of $50 \mathrm{ml}$ in liquid nitrogen and stored at $-80^{\circ} \mathrm{C}$.

\section{RNA EXTRACTION AND REAL-TIME QUANTITATIVE PCR}

About $2 \mathrm{~g}$ of tissue from each sample collected was ground in liquid N2. Total RNA from root and leaf tissue of two developmental stages was extracted by RNeasy Plant Mini Kit (Qiagen). Pods were extracted following a protocol optimized for high starch samples ( $\mathrm{Li}$ and Trick, 2005). Total RNA was stored in aliquots at $-80^{\circ} \mathrm{C}$. The concentration of RNA was quantified through Quant-iT ${ }^{\mathrm{TM}}$ RiboGreen (Invitrogen). Two $\mu \mathrm{g}$ of RNA of each sample were treated with DNase I and purified by 0.1 vol of $3 \mathrm{M}$ sodium acetate $(\mathrm{pH} 5.2$ ) and 3 vol of $100 \%$ ethanol. cDNA synthesis was carried out by High Capacity cDNA Reverse Transcription Kits (Applied Biosystem), using $1 \mu \mathrm{g}$ of RNA. cDNA concentration was measured by Quant-iT ${ }^{\mathrm{TM}}$ PicoGreen (Invitrogen).

The relative expression levels of eighth ZIP genes; $P v Z I P 2$, PvZIP7, PvZIP6, PvZIP12, PvZIP13, PvZIP16, PvZIP18, and $P v I R T 3$ and three transcription factors belonging to the bZIP family, bZIP1, bZIP2, bZIP3 were measured using RT-qPCR. Primers for RT-qPCR were designed for each gene in such a way that they spanned one or two exons in genes with intronic regions to detect genomic DNA contamination (Table 1). Quantification of all transcripts was performed using the SuperScript III Platinum SYBR Green One-Step qRT-PCR Kit (Invitrogen, Carlsbad, CA) according to the manufacturer's instructions. In total three technical replicates of $50 \mathrm{ng}$ of cDNA for each biological replicate of all tissues were used as template. Ten-fold serial dilutions were used to determine the efficiencies of each primer. RT-qPCR master-mix was prepared as follows: $1 \mu \mathrm{l}$ of diluted cDNA, $5 \mu \mathrm{l}$ of $2 \mathrm{X}$ SYBR Green Reaction Mix, $0.5 \mu \mathrm{l} 3 \mathrm{pmol}$ of each primer and nuclease-free water in a final volume of $10 \mu \mathrm{l}$. The StepOnePlus ${ }^{\mathrm{O}}$ Real-Time PCR System (Applied Biosystems) was used for amplification and fluorescence measurement of each transcript at each temperature step and cycle during the reaction. Thermal cycling conditions consisted of $10 \mathrm{~min}$ at $95^{\circ} \mathrm{C}$ followed by 40 cycles of $15 \mathrm{~s}$ at $95^{\circ} \mathrm{C}$ and $45 \mathrm{~s}$ at $60^{\circ} \mathrm{C}$. The identity and purity of the amplified product was checked through analysis of the melting curve carried out at the end of amplification. Relative gene expression was calculated using the comparative CT method (Livak and Schmittgen, 2001). bActin was used as a reference gene and root in vegetative stage $\mathrm{Zn}(-)$ treatment as a calibrator (Wen et al., 2005). Fold changes of greater than 2 was used as criteria to determine if genes were differentially expressed. Statistical analysis was performed using SAS V 9.3 (SAS Institute Inc., NC, USA). A repeated measurement analysis (Proc Mixed) was performed. Main effects were tested by ANOVA and a probability of $P<0.05$ was chosen as the level of significance for the statistical test.

\section{QUANTIFICATION OF Zn CONCENTRATIONS IN TISSUE}

Plant tissue from two biological replicates of DOR364 and G19833 under two zinc treatments was quantified for $\mathrm{Zn}$ concentration. Tissue was freeze dried and ground to powder using a Geno Grinder 2000 (Spex CertiPrep, Metuchen, NJ) and zircon grinding balls. Two grams were sent to A\&L Great Lakes Labs, Inc. Fort Wayne, IN, for mineral analysis by induced coupled plasma spectroscopy.

\section{RESULTS \\ IDENTIFICATION OF ZIP FAMILY MEMBERS AND COMPARISON WITH HOMOLOGS IN OTHER SPECIES}

Twenty three sequences, including 19 ZIP and four IRT genes were identified in the $P$. vulgaris genome sequence based on similarity to ZIP genes in A. thaliana and/or Medicago truncatula. All new genes have full-length CDS containing open reading frames (ORF) ranging from 153 to 655 amino acids in length. Sequences identified were confirmed in the PFAM database based on ZIP transmembrane domain and had E-values higher than -10 . Peptide sequences of all new ZIP genes identified in common bean were aligned with 18 ZIP genes reported in the A. thaliana, and M. truncatula (Table 2). A phylogenetic neighbor joining tree shows the relationship among ZIP genes in P. vulgaris, A. thaliana, and M. truncatula (Figure 1). Alignments at the amino acid level predicted eight highly conserved transmembrane domains (Figure 2) and a potential metal binding motif containing histidine residues implicated in metal transport which are highly conserved throughout the entire family (Guerinot, 2000; Lopez-Millan et al., 2004). All ZIP genes contained a histidine motif between transmembrane domain III and IV except PvZIP6, PvZIP7, and PvZIP18. The ZIP gene family members in $P$. vulgaris shared $3-81.4 \%$ homology to each other. Of all ZIP genes found PvIRT3 was the most closely related to Arabidopsis, sharing 59 and $57.3 \%$ similarity with genes AtIRT3_AT1G60960.1 and AtZIP4_AT1G10970, respectively. PvZIP14 also showed high similarity with AtZIP6_AT3G30080.1 at $53.8 \%$.

Gene structure analysis of ZIP genes in P. vulgaris revealed that the 23 genes have different intron-exon structures with a wide range of lengths. PvZIP2, PvZIP6, PvZIP7, PvZIP15, and $P v I R T 1$, are composed of three exons and two introns. PvZIP3, PvZIP5, PvZIP9, PvZIP10, PvZIP11, PvZIP13, PvZIP16, PvZIP19, and $P v I R T 2$ each have four exons and three introns. $P v Z I P 17$ and $P v I R T 3$ have five exons and four introns. Seven exons were identified in PvZIP1 and PvIRT4. Many exons (10-14) were present in PvZIP4, PvZIP8, PvZIP12, PvZIP14, and PvZIP18.

Given the importance of some members of the bZIP gene family in the regulation of ZIP genes and in turn plant Zn homeostasis, their sequences were also characterized in the P. vulgaris genome. The common bean genes $b Z I P 1, b Z I P 2$ and $b Z I P 3$ were 261, 266 and 154 amino acids long, respectively. None of the bZIP genes contained introns. The three amino acids sequences encoding the bZIP genes shared 4.0-38.5\% similarity among each other and $15-55.4 \%$ similarity with $b Z I P 19, b Z I P 23$, and bZIP24 genes described in A. thaliana (Assunção et al., 2010).

\section{MAPPING OF PvZIP GENES AND OTL FOR SEED Fe AND Zn CONCENTRATION}

ZIP and bZIP were mapped in silico on the DOR364 × G19833 genetic map by aligning ZIP gene sequences and molecular 


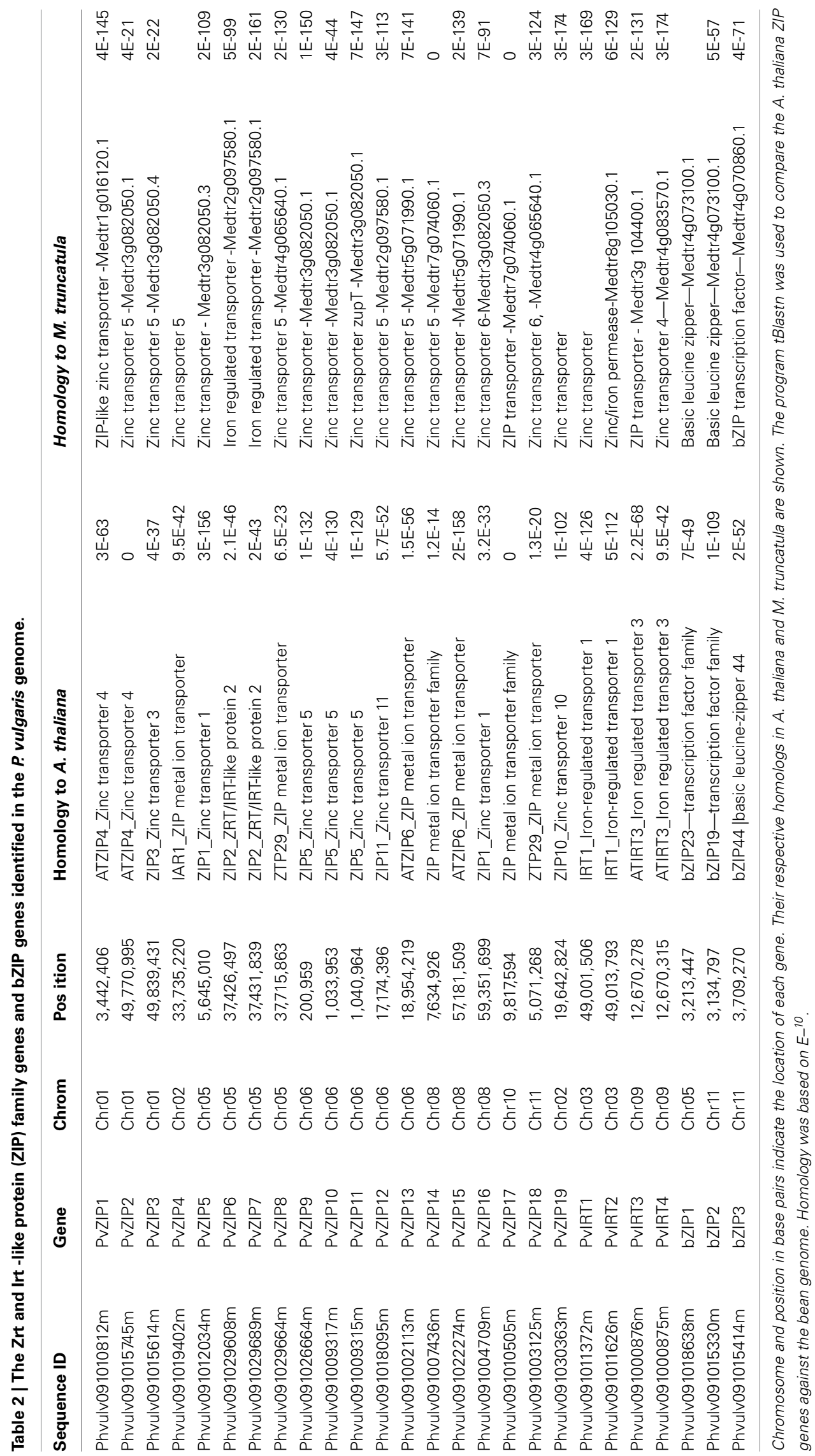




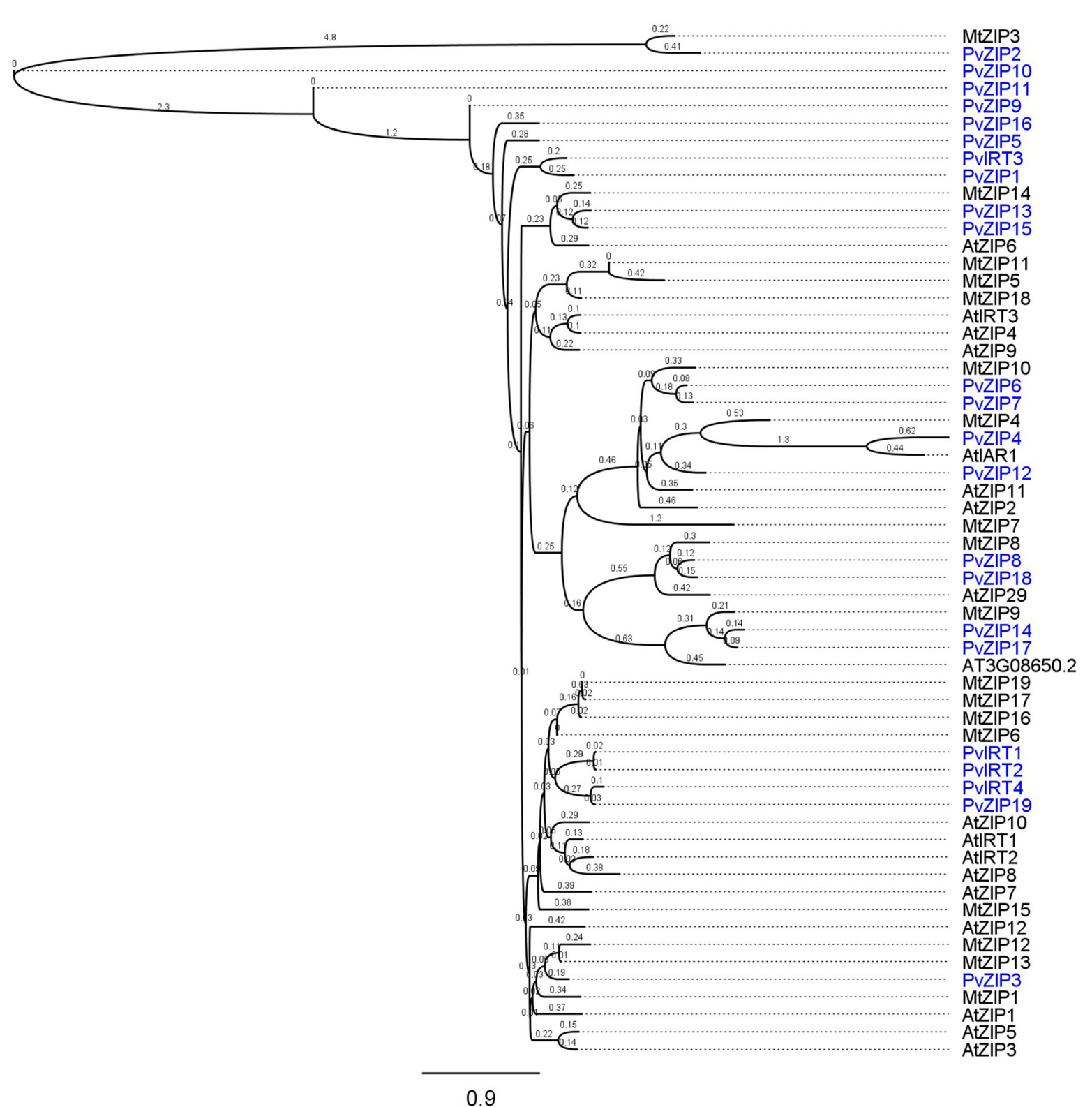

FIGURE 1 | Phylogenetic tree of homologs ZRT, IRT-like protein family in Phaseolus vulgaris, Arabidopsis thaliana, and Medicago truncatula. Analysis was based on alignment of amino acid sequences using Geneious program v. 6.0 .3 and $\mathrm{N}-\mathrm{J}$ trees were generated. Arabidopsis genes are indicated with the ZIP and IRT number used on TAIR database. ZIP names used in Medicago were according to Lopez-Millan et al. (2004) (ZIP1 to ZIP7). ZIP8 in front were assigned with a consecutive number. marker sequence in DOR $364 \times$ G19833 against the $P$. vulgaris genome sequence. The results of the in silico mapping indicate that ZIP genes are distributed on all P. vulgaris chromosomes except 4 and 7. There was a tendency for ZIP genes to cluster together, most notably on chromosome 5 and 6 (Figure 3 ).

Through in silico mapping, bZIP1 was located on chromosome 5 and $b Z I P 2$ and $b Z I P 3$ were located near each other on chromosome 11. The bZIP3 gene location was expected based on the position and sequence of the SNP marker g785 which contains the bZIP domain. This marker was described as PvMcCleanNDSU2007_11_g785 (http://cmap. comparative-legumes.org). Selected ZIP genes were also mapped genetically via DNA polymorphisms in the DOR364 × G19833 population using the $P$. vulgaris reference genetic map published by Galeano et al. (2011). This map consists of 499 single copy markers and $2306 \mathrm{cM}$ of coverage (Figure 3). PvZIP2, PvZIP6PvZIP8, PvZIP13, and PvIRT3 mapped to chromosomes 1, 5, 6, and 9 , respectively.

Once gene markers were mapped, QTLs for seed Fe and Zn were also identified on this map. These QTLs include previously 


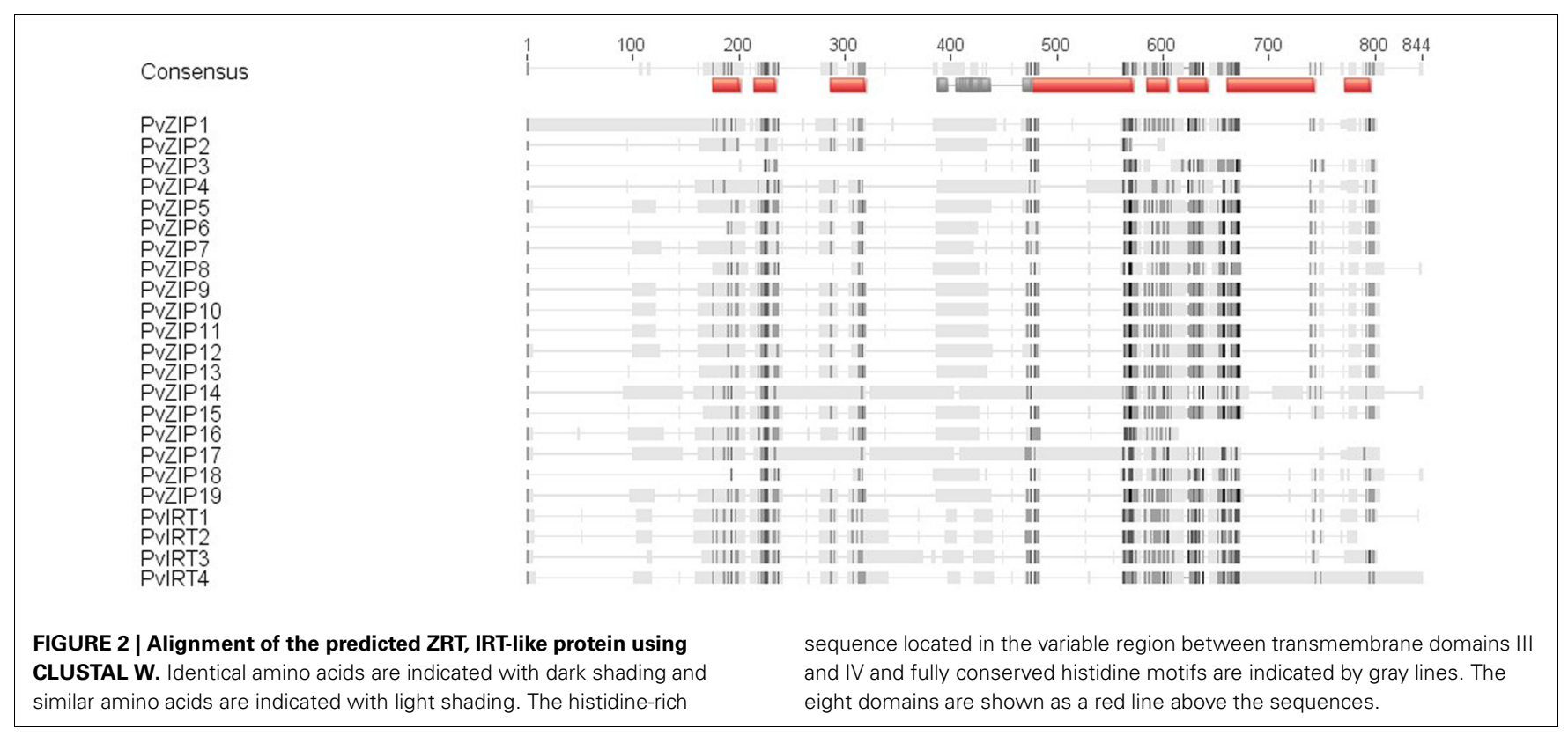

published data for two sites (Blair et al., 2009) as well as QTL identified in whole and cotyledon seed mineral evaluation from a 2006 planting of the same population in Darien, Colombia. QTL analysis in the 2006 evaluation identified new QTLs for Zn concentration on chromosomes 1 and 2 and also confirmed the QTLs identified by Blair et al. (2009) (Table 3). For seed Fe concentration, 13 QTLs were found on chromosomes 2, 3, 6, 8, and 11. For seed Zn concentration 11 QTLs were found on 1, 2, 3, 6, 9, and 11 (Table 3). ZIP genes mapped on chromosomes 3, 6,8 , and 11 mapped within the regions of QTL for Fe and/or $\mathrm{Zn}$. On chromosome 11 two bZIP genes (with genomic position 3,134,797 and 3,709,270 bp) were mapped in silico within the region of two QTLs for seed Fe and one QTL for seed Zn (Figure 3). Two $P v$ IRT genes are present on chromosome 3 (at 49,001,506 and 49,013,793 bp) and three QTLs for seed Fe concentration mapped between the QTLs (Figure 3). Table 3 shows specifically which ZIP genes are located within or nearby QTL for seed mineral concentration.

\section{EXPRESSION ANALYSIS OF PvZIP GENES}

Studies in Arabidopsis, Glycine, Vitis and Medicago indicate that ZIP genes may be expressed in roots, leaves, and reproductive tissue (Grotz et al., 1998; Lopez-Millan et al., 2004). Many studies so far have focused on expression in roots and shoots (Grotz et al., 1998; Lopez-Millan et al., 2004; Milner et al., 2012). From the perspective of biofortification, it is necessary for a bean plant not only to efficiently take up $\mathrm{Zn}$ from the soil, but also transport and accumulate it in vegetative tissue, pods, and ultimately seeds. In order to determine the expression profile of members of ZIP family and their relevance during the development of common bean, relative expression levels were measured by RT qPCR. PvZIP2, PvZIP7, PvZIP6, PvZIP12, PvZIP13, PvZIP16, PvZIP18, and $P v I R T 3$ genes were selected for this analysis based on their location in the genome in relation to presence of QTLs for Zn and Fe in the DOR364 $\times$ G19833 population. Three tissue types were analyzed for gene expression in DOR364 and G19833: roots, leaves, and pods. Roots and leaves were collected at two time points, one during vegetative growth, and one during flowering. Pods were sampled 20 days after flowering. Each tissue type was selected from plants with two $\mathrm{Zn}$ treatments. At four weeks after planting, DOR364 and G19833 plants in the Zn (-) treatment exhibited some $\mathrm{Zn}$ deficiency symptoms such as interveinal chlorosis, bronzing, and shortening of the internode (Brown and Leggett, 1967). The ZIP genes PvZIP12, PvZIP13, PvZIP16, and PvIRT3 were expressed in all tissue analyzed (Figure 4). However, $P v Z I P 2, P v Z I P 6, P v Z I P 7$, and $P v Z I P 18$ were undetectable under RT qPCR in all tissue types. This finding is also supported by pod transcriptome data which also found low to no expression for PvZIP2, PvZIP6, PvZIP7, and PvZIP18 (Astudillo et al., in preparation).

Gene expression of PvZIP12 and PvZIP16 was induced upon Zn status in leaf tissue. $P v Z I P 12$ was most highly expressed in leaves at vegetative stage under $\mathrm{Zn}(-)$ treatment, especially in G19833 (Figure 4). For PvZIP13, G19833 was more highly expressed than DOR364 especially in leaves sampled during flowering. Of each of the ZIP genes studied, PvZIP16 showed the highest differential expression based on tissue type, stages, and zinc treatment but not between genotypes. It was 139-848-fold more expressed in the leaves than the roots for both genotypes and developmental stages.

\section{EXPRESSION ANALYSIS OF THREE TRANSCRIPTION FACTORS $\boldsymbol{b Z I P}$}

RNA from the same samples described above were also used to determine the relative expression of three transcription factors $P v$ bZIP1, Pv bZIP2 and Pv bZIP3, which are homologous to Arabidopsis bZIP genes in the zinc homeostasis network (Table 2). The common bean homologue bZIP1 was detected in roots, leaves, (at vegetative stages) and pods but expression pattern did not change based on stages and $\mathrm{Zn}$ treatment. This gene was more highly expressed in leaf tissue sampled during flowering than 

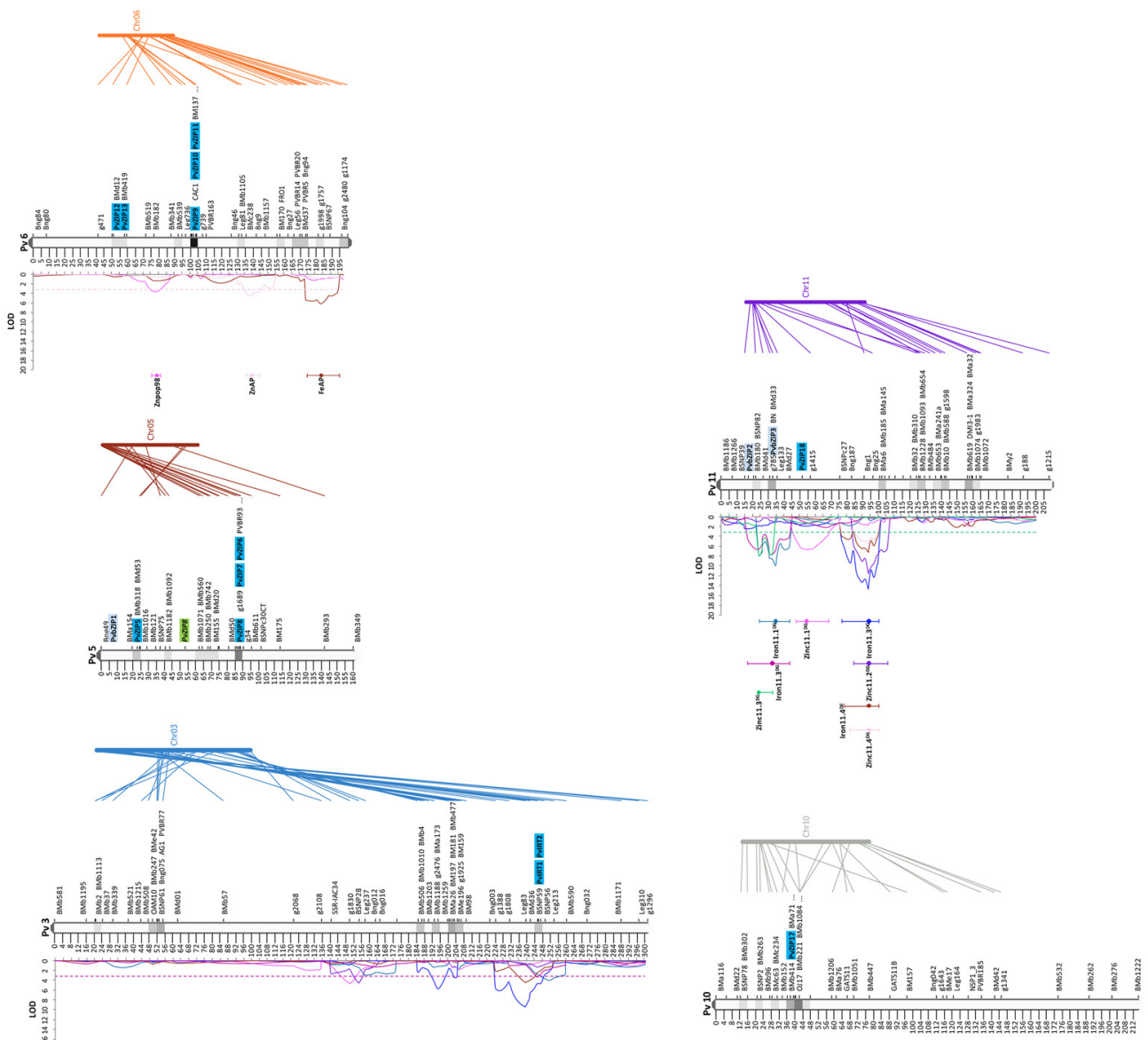

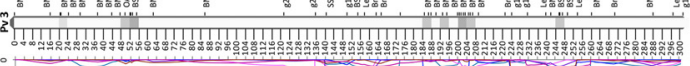
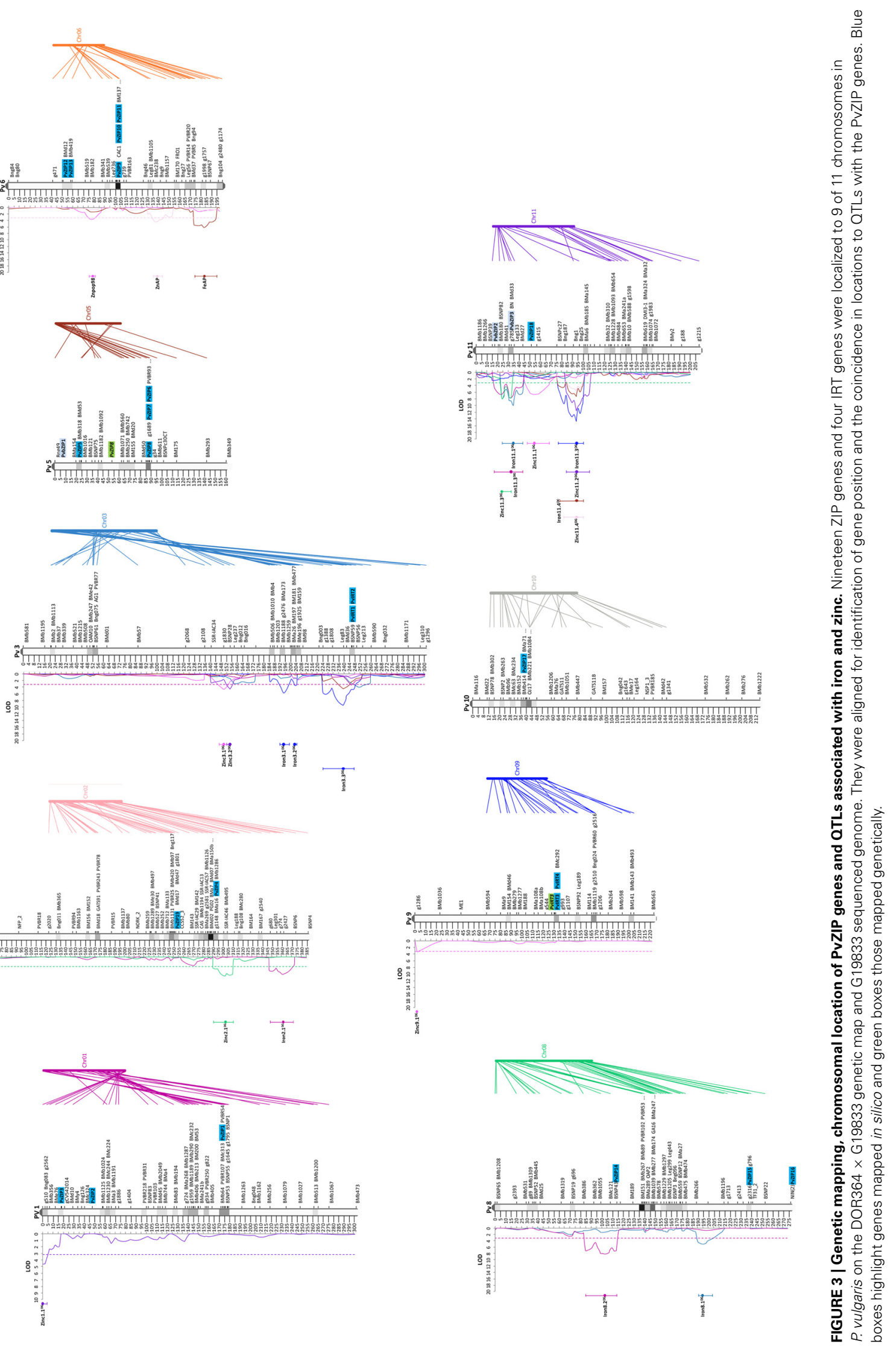


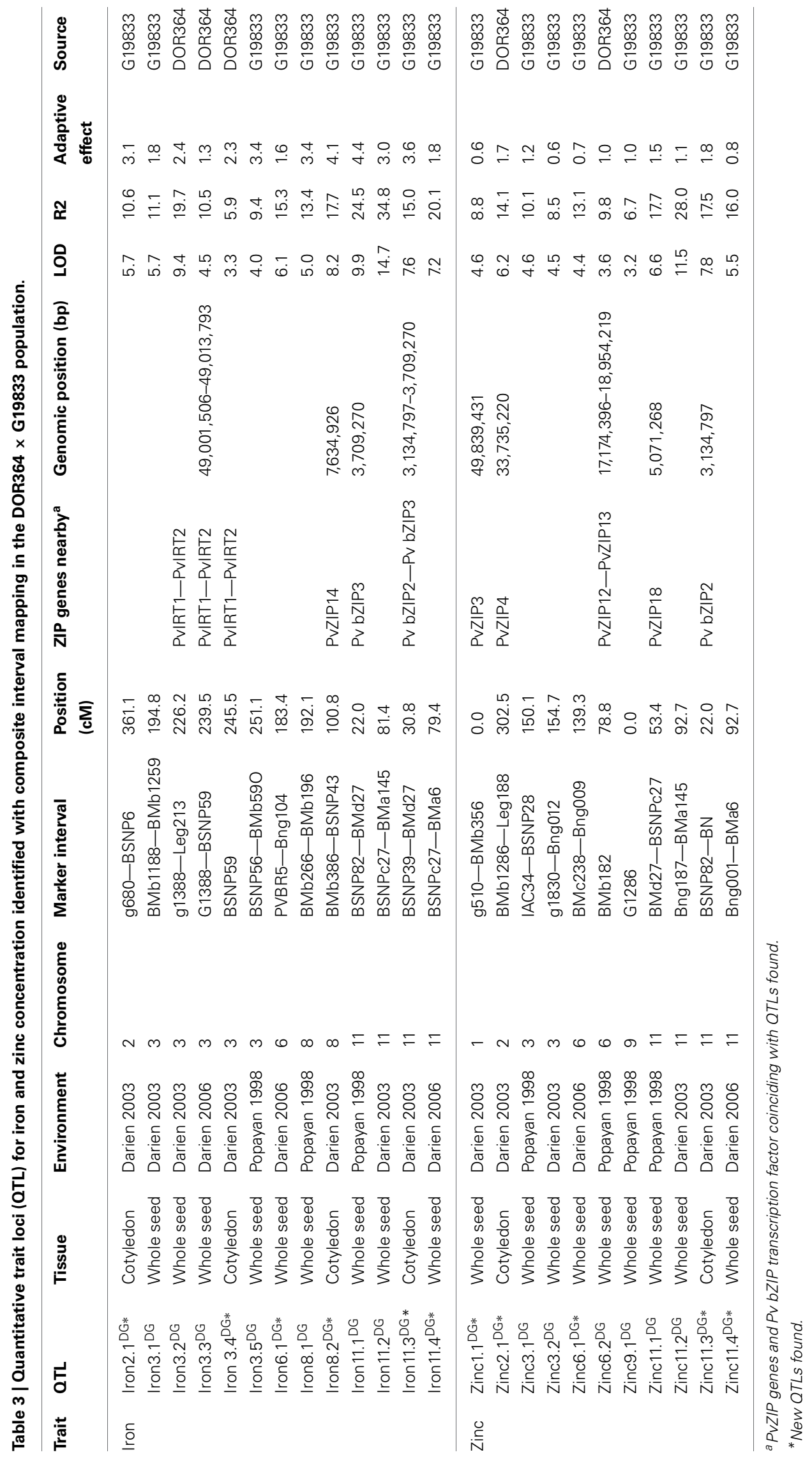



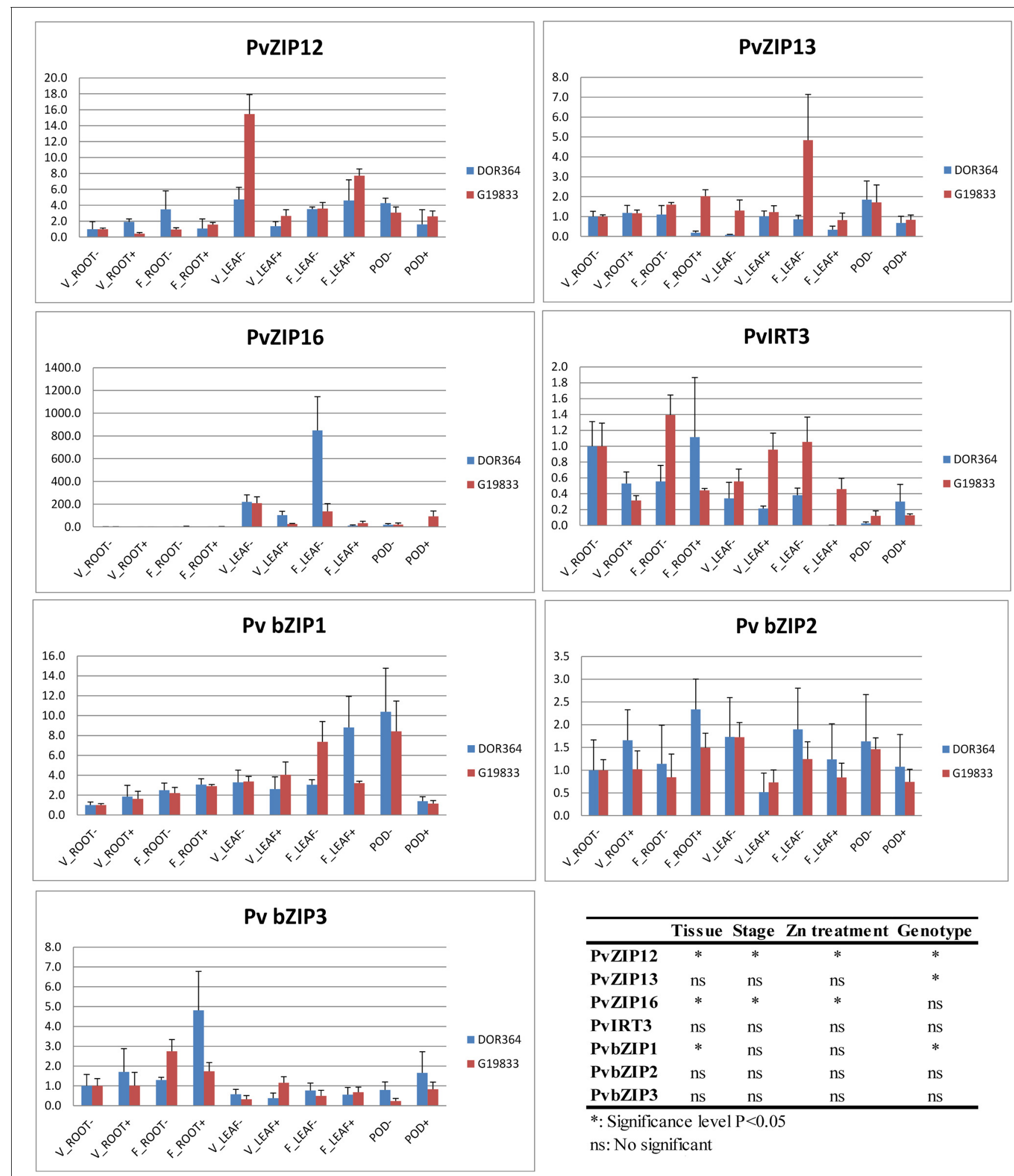

FIGURE 4 | Relative expression level of PvZIP gene transporters and three bZIP transcription factors in genotypes Dor364 and G19833 in different tissues and two Zn treatment. (i) roots at vegetative stage (V_ROOT- and $V_{-}$ROOT+), (ii) roots at flowering

stage (F_ROOT- and F_ROOT+); (iii) leaves at vegetative stage (V_LEAF- AND V_LEAF+) stage; (iv) leaves at flowering stage (F_LEAF- and F_LEAF+); and ( $v$ ) pods (POD- and POD+) of plants under $\mathrm{Zn}(-)$ and $\mathrm{Zn}(+)$ treatment.

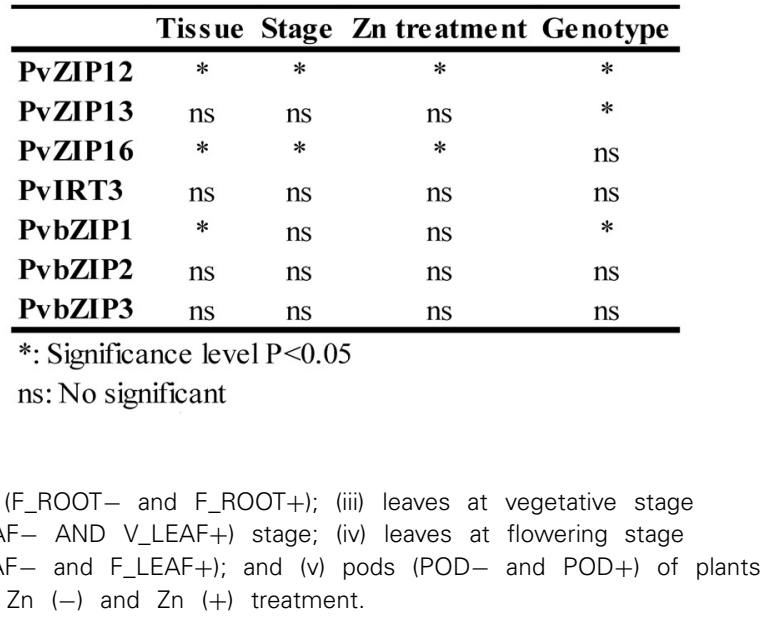


vegetative tissue in both G19833 and DOR364. Transcripts of $P v$ bZIP2 were detected in roots, leaves, and pods and its expression pattern was not influenced by tissue type, developmental stage or Zn treatment. $P v b Z I P 3$ was expressed in roots during vegetative and flowering with a barely expression in leaves and pods.

\section{TISSUE ZINC CONCENTRATION}

Zn concentration was determined for DOR364 and G19833 for all tissues, developmental stages, and $\mathrm{Zn}$ treatments (Figure 5). The highest $\mathrm{Zn}$ concentration was observed in roots for both genotypes and no significant differences were observed in leaves. Significant tissue $\times \mathrm{Zn}$ treatment $\times$ genotype interaction was found. Plants grown under the $\mathrm{Zn}(+)$ treatment had higher levels of $\mathrm{Zn}$ in pods and seeds than those grown under the $\mathrm{Zn}(-)$ treatment. Seed $\mathrm{Zn}$ levels were 26 and $53 \%$ less in the $\mathrm{Zn}(-)$ treatment in DOR364 and G19833, respectively. G19833 had higher seed Zn levels that DOR364 under the $\mathrm{Zn}(+)$ treatment but not under the $\mathrm{Zn}(-)$ treatment (Figure 5).

\section{DISCUSSION}

Common bean is becoming an alternative to dietary supplements as a way to improve human health. ZIP metal transporters are one of the most important gene families for $\mathrm{Zn}$ and Fe cellular uptake and translocation in plants (Guerinot, 2000; Chen et al., 2008; Wu et al., 2009; Adams et al., 2012). Identification of ZIP members in $P$. vulgaris and characterization of their expression patterns is useful to increase the understanding of uptake, transportation, and storage of $\mathrm{Zn}$. This study is a unique combination of gene family characterization with physical and genetic mapping and functional expression data that has utility in common bean improvement.

Twenty-three ZIP genes were identified in the $P$. vulgaris genome and genes were annotated and characterized based on similarity to other ZIP family members in A. thaliana and $M$. truncatula. According to the total number ZIP family members across species the family origin may be from a common ancestor that has undergone sequence duplication followed by divergence events (D'Ovidio et al., 2004). PvZIP genes clustered on chromosomes 3, 5, 6, and 9 showed high sequence similarity. The close proximity and sequence similarity of many of the ZIP gene family members might suggest of gene duplication followed by diversification (Yang et al., 2009). On the other hand, heterogeneity in structure and expression in each PvZIP gene suggests diversity in functionality. Four of the eight genes evaluated were not expressed in none of the tissue analyzed. Loss of function in these proteins might be compensated for by duplicate genes (D'Ovidio et al., 2004).

It is important to consider the link between functional variation and gene structural differences among ZIP family members. In many cases, $\mathrm{Zn}$ interacts with cysteines and histidines in proteins and may determine the ionic selectivity of ion transporters (Ramesh et al., 2003; Lopez-Millan et al., 2004). The motif of histidine in variable regions between transmembrane domain III and IV in many ZIPs has been postulated to serve as a potential metal ion binding site (Eide et al., 1996; Zhao and Eide, 1996; Grotz et al., 1998). For PvZIPs identified in this study, all contained this motif except $P v Z I P 6, P v Z I P 7$, and $P v Z I P 18$, interestingly these ZIP genes were also not expressed in all tissue analyzed, suggesting without the motif they are not functional.

In Arabidopsis, ZIP genes have been shown to regulate and also contribute to the uptake, transport and accumulation of $\mathrm{Zn}$ (Grotz et al., 1998; Weber et al., 2004; Talke et al., 2006; Lin et al., 2009; Milner et al., 2013). Here we used RT-qPCR approach to obtain a picture of ZIP gene transcription in roots and leaves at vegetative and flowering stages, and pods at 20 days after flowering in P. vulgaris. Some processes such as $\mathrm{Zn}$ uptake, have been studied in detail, while others such as remobilization of $\mathrm{Zn}$ from vegetative to reproductive tissues are less well understood

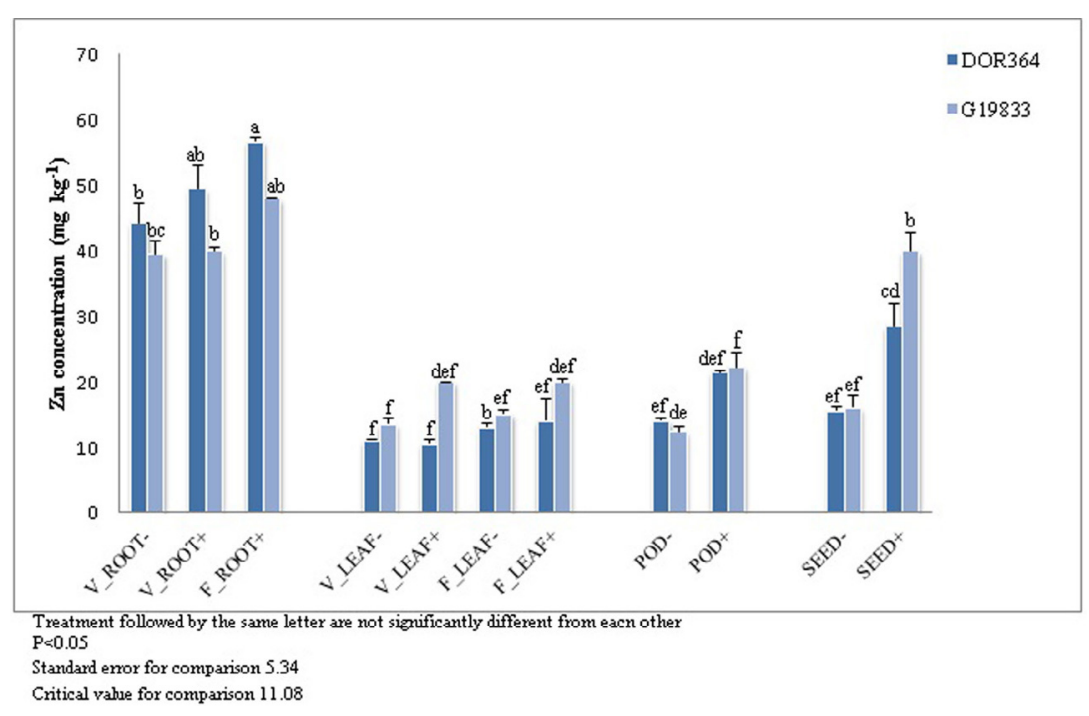

FIGURE 5 | Zinc concentration in DOR364 and G19833. Zn concentration (ppm) in (i) roots at vegetative stage (V_ROOT - and V_ROOT+), (ii) roots at flowering stage (F_ROOT+); (iii) leaves at vegetative stage (V_LEAF- AND
V_LEAF+) stage; (iv) leaves at flowering stage (F_LEAF- and F_LEAF+); (v) pods (POD- and POD+) and seeds (SEED - and SEED+) of plants under Zn $(-)$ and $\mathrm{Zn}(+)$ treatment. 
(Genc et al., 2006). The evaluation of gene expression patterns based on tissue, $\mathrm{Zn}$ treatments, and genotype not only provides information on the functionality of the ZIP family genes but also may help explain genotypic differences in seed $\mathrm{Zn}$ accumulation. These data indicate differential gene regulation associated with the nutritional requirements and possible mechanism of partitioning of $\mathrm{Zn}$ along the plant. According to ZIP genes characterization in Arabidopsis approximately half of the genes characterized are induced in response to $\mathrm{Zn}$ deficiency (Grotz et al., 1998; Talke et al., 2006).

ZIP gene expression differences in $P$. vulgaris were related to $\mathrm{Zn}$ treatments, genotype, and tissue type. Genotypic differences in $\mathrm{Zn}$ translocation capacity in different organs may be an important factor in $\mathrm{Zn}$ accumulation in seeds (Hacisalihoglu et al., 2004). Observed differences between genotypes could also be due to genetic differences and diversity among Andean and Mesoamerican gene pools (Blair et al., 2009). Similarly to previous studies, G19833 had higher seed Zn level than DOR364 (Blair et al., 2009). However DOR364 had higher $\mathrm{Zn}$ in its roots as compared to G19833 suggesting that G19833 can translocate more Zn from roots to seeds.

Zinc plays a specific role in fertilization and pollen grains contain very high concentrations of Zn (Fageria et al., 2011). At flowering most of the $\mathrm{Zn}$ taken up is incorporated into the developed seed (Jiang et al., 2008) so genes highly expressed at flowering and in pods such as PvZIP12, PvZIP16, and $b Z I P 1$ could be directly related to $\mathrm{Zn}$ remobilization to seeds.

Although leaves are known as the major source of remobilized micronutrients in common bean (Sekara et al., 2005) in rice stems are the major source of $\mathrm{Zn}$ in the seed (Waters and Sankaran, 2011). With this study it was not possible to determine how much and the source of $\mathrm{Zn}$ remobilization. Future studies with radio labeled $\mathrm{Zn}$ would be warranted to asses $\mathrm{Zn}$ remobilization.

Based on the relative expression values established via RTqPCR, the high $\mathrm{Zn}$ concentration in roots did not reflect expression values for the ZIP genes evaluated in this tissue. In Arabidopsis at least 10 different members of the ZIP family play a role in zinc uptake in roots, including ZIP1, 2, 3, 4, 5, 9, 10, 11, 12, and IRT3 (Van De Mortel et al., 2006). We evaluated four of their respective homologous in $P$. vulgaris and found that they were only weakly expressed in roots.

The DOR364 × G19833 RILs mapping population consists of 86 individuals, which are adequate for identifying QTL with moderately large effects based on QTLs previously detected (Blair et al., 2009, 2011; Galeano et al., 2011). In silico mapping of ZIP genes was a successful strategy to locate PvZIP genes aligned

\section{REFERENCES}

Adams, J. P., Adeli, A., Hsu, C.H., Harkess, R. L., Page, G. P., dePamphilis, C. W., et al. (2012). Characterization of Poplar ZIP family members ZIP1.2 and ZNT1. J. Plant Genet. Transgenics 3, 1-13.

Afoufa-Bastien, D., Medici, A., Jeauffre, J., Coutos-Thevenot, R. A., Lemoine, R., Atanassova, R., et al. (2010). The Vitis vinifera sugar transporter gene family: phylogenetic overview and macroarray expression profiling. BMC Plant Biol. 10:245. doi: 10.1186/1471-2229-10-245

Ahuja, J. K. A., Montville, J. B., OmolewaTomobi, G., Heendeniya, K. Y., Martin, C. L., Steinfeldt, L. C., et al. (2012). USDA Food and Nutrient Database for Dietary Studies, 5.0 U.S. Department with QTL for seed Fe and Zn in the bean genome. QTL analysis was carried out in the current reference bean map (Galeano et al., 2011). It is worth noting that on chromosomes 2 and 6 where PvZIP4 and PvZIP12 and PvZIP13 are located, there are QTL for seed Zn concentration. For Fe, the IRT genes are considered to be the main transporters for high-affinity iron uptake in roots in Arabidopsis (Connolly et al., 2002; Henriques et al., 2002; Lin et al., 2009). In this study, PvIRT1 and PvIRT2 were located on chromosome 3 within an important QTL region associated with seed Fe concentration. The Pv bZIP2 and $P v$ bZIP3 genes were located on chromosome 11 and aligned with the most important QTL for Fe and Zn reported in P. vulgaris. There are no obvious genotypic differences in expression of these genes in G19833 and DOR 364, however. The QTL in this region has been found in at least three mapping populations, including Mesoamerican and Andean intra and inter genepool crosses (Blair et al., 2009, 2010a,b, 2011). The bZIP transcription factors analyzed correspond to genes in Arabidopsis responsible for response and adaptation to low $\mathrm{Zn}$ supply. In general, $P v Z I P$, $P v \mathrm{IRT}$, and $P v$ bZIPs co-localization with QTLs for Fe and $\mathrm{Zn}$ levels suggest that their function is important in $\mathrm{Fe}$ and $\mathrm{Zn}$ homeostasis in P. vulgaris. In Arabidopsis, the bZIP transcription factors that interacted with ZIP genes were found directly upstream of the ZIP genes (Assunção et al., 2010). In the case of $P$. vulgaris none of the bZIP genes were adjacent to ZIP genes.

This study is the first to characterize the ZIP gene family, report the expression profile in various tissues with two genotypes and fertilization treatments. It provides evidence of the relationship among level of transcripts and QTLs in dry bean seed as was identified in PvZIP12 gene. This contribution will be particularly useful for advancing bean breeding programs. The use of such gene marker encoding proteins associated with transport and accumulation of $\mathrm{Zn}$ and Fe could increase the efficiency and accuracy in the selection of breeding materials for biofortification.

\section{ACKNOWLEDGMENTS}

We are grateful to International Center for Tropical Agriculture (CIAT) especially to Dr. Steve Beebe for providing seed of DOR364 and G19833 genotypes used in this study and the phenotypic data of their RIL population. We are very grateful to the two reviewers of Frontiers in Plant Sciences for their appropriate and constructive suggestions to improve the paper. We thank Michigan State University Plant Breeding Genetics and Biotechnology Program for providing an assistantship for C. Astudillo.
U.S.A. 107, 10296-10301. doi: 10.1073/pnas. 1004788107

Assuncao, G. L., Ten, B., Nelissen, H. J. M., Vooijs, R., Schat, H., and Ernst, W. (2003). A cosegregation analysis of zinc $(\mathrm{Zn})$ accumulation and $\mathrm{Zn}$ tolerance in the $\mathrm{Zn}$ hyperaccumulator Thlaspi caerulescens. New Phytol. 159, 383-390. doi: 10.1046/j.1469-8137. 2003.00758.x 
Balarajan, Y., Selvaraj, S., Subramanian, S. V. (2011). Health care and equity in India. Lancet 377, 505-515. doi: 10.1016/S0140-6736(10)61894-6

Beebe, S. E., Rojas-Pierce, M., Yan, X. L., Blair, M. W., Pedraza, F., Muñoz, F., et al. (2006). Quantitative trait loci for root architecture traits correlated with phosphorus acquisition in common bean. Crop Sci. 46, 413-423.

Blair, M. W., Astudillo, C., Grusak, M., Graham, R., and Beebe, S. (2009). Inheritance of seed iron and zinc concentrations in common bean (Phaseolus vulgaris L). Mol. Breed. 23, 197-207. doi: 10.1007/s11032008-9225-Z

Blair, M. W., Astudillo, C., Rengifo, J., Beebe, S. E., and Graham, R. (2011). QTL analyses for seed iron and zinc concentrations in an intra-genepool population of Andean common beans (Phaseolus vulgaris $L$ ). Theor. Appl. Genet. 122, 511-521. doi: 10.1007/s00122-010-1465-8

Blair, M. W., Medina, J. I., Astudillo, C., and Beebe, S. E. (2010a). QTL for seed iron and zinc concentration and content in a Mesoamerican common bean (Phaseolus vulgaris L) population Theor. Appl. Genet. 121, 1059-1070. doi: 10.1007/s00122-010-1371-0

Blair, M., Knewtson, S. J. B., Astudillo, C., Li, C.-M., Fernandez, A. C., and, Grusak, M. A. (2010b). Variation and inheritance of iron reductase activity in the roots of common bean (Phaseolus vulgaris L) and association with seed iron accumulation QTL. BMC Plant Biol. 10:215. doi: 10.1186/1471-2229-10-215

Blair, M. W., Pedraza, F., Buendia, H. F., Gaitán-Solís, E., Beebe, S. E., Gepts, P., et al. (2003). Development of a genome-wide anchored microsatellite map for common bean (Phaseolus vulgaris L.). Theor. Appl. Genet. 107, 1362-1374.

Bouis, H. E., Hotz, C., McClafferty, B., Meenakshi, J. V., and Pfeiffer, W. H. (2011). Biofortification: a new tool to reduce micronutrient malnutrition. Food Nutr. Bull. 32, 31S-40S.

Brown, J. W., and Leggett, G. E. (1967). "Zinc deficiency symptoms of beans," in Proceedings of the 18th Annual Fertilizer Conference of the Pacific Northwest, Twin Falls, (Portland, OR: Northwest Plant Food Assoc.), 165-172.

Chen, W. R., Feng, Y., and Chao, Y. E. (2008). Genomic analysis and expression pattern of OsZIP1, OsZIP3, and OsZIP4 in two rice (Oryza sativa L) genotypes with different zinc efficiency. Russ. J.
Plant Physiol. 55, 400-409. doi: 10.1134/S1021443708030175

Cichy, K. A., Blair, M. W., Galeano, C. H., Snapp, S. S., and Kelly, J. D. (2009). QTL analysis of root architecture traits and low phosphorus tolerance in an Andean bean population. Crop Sci. 49, 59-68.

Connolly, E., Fett, J. P., and Guerinot, M. (2002). Expression of the IRT1 metal transporter is controlled by metals at the levels of transcript and protein accumulation. Plant Cell 14, 1347-1357. doi: 10.1105/tpc 001263

D’Ovidio, R., Raiola, A., Capodicasa, C., Devoto, A., Pontiggia, D., Roberti, S., et al. (2004) Characterization of the complex locus of bean encoding polygalacturonase-inhibiting proteins reveals subfunctionalization for defense against fungi and insects. Plant Physiol. 135, 2424-2435.

Eide, D. M., Broderius, J. F., and Guerinot, M. L. (1996). A novel iron-regulated metal transporter from plants identified by functional expression in yeast. Proc. Natl. Acad. Sci. U.S.A. 93, 5624-5628. doi 10.1073/pnas.93.11.5624

Eng, B. H., Guerinot, M. L., Eide, D. and Saier, M. H. (1998). Sequence analyses and phylogenetic characterization of the ZIP family of metal ion transport proteins. J. Memb. Biol. 166, 1-7. doi: $10.1007 / \mathrm{s} 002329900442$

Fageria, N. K., Dos Santos, A. B., and Cobucci, T. (2011). Zinc nutrition of lowland rice. Comm. Soil Sci. Plant Anal. 42, 1719-1727. doi: 10.1080/00103624.2011.584591

Fernandez, A. C., Galeano, C. H. Cichy, K. A., and Blair, M. W. (2011). "MapSynteny: Software to create images of synteny," in Plant Breeding Genetics and Biotechnology Symposium, East Lansing, USA.

Gainza-Cortes, F., Perez-Diaz, R., Perez-Castro, R., Tapia, J., Casaretto, J. A., González, S., et al. (2012). Characterization of a putative grapevine Zn transporter, VvZIP3, suggests its involvement in early reproductive development in Vitis vinifera L. BMC Plant Biol. 12:111. doi: 10.1186/1471-2229-12-111

Galeano, C., Fernandez, A. C., Franco-Herrera, N., Cichy, K. A., McClean, P. E., Vanderleyden, J., et al. (2011). Saturation of an Intra-Gene Pool Linkage Map: towards a unified consensus linkage map for fine mapping and Synteny Analysis in Common Bean. PLoS ONE 6:e28135. doi: 10.1371/journal.pone.0028135
Galeano, C. H., Fernandez, A. C. Cichy, K. A., and Blair, M. W. (2009). Single strand conformation polymorphism based SNP and Indel markers for genetic mapping and synteny analysis of common bean (Phaseolus vulgaris L). BMC Genomics 10:629. doi 10.1186/1471-2164-10-629

Genc, Y., McDonald, G. K., and Graham, R. D. (2006). Contribution of different mechanisms to zinc efficiency in bread wheat during early vegetative stage. Plant Soil 281 , 353-367.

Grotz, N., Fox, T., Connolly, E., Park, W., Guerinot, M., and Eide, D. (1998). Identification of a family of zinc transporter genes from Arabidopsis that respond to zinc deficiency. Proc. Natl. Acad. Sci. U.S.A. 95, 7220-7224. doi: 10.1073/ pnas. 95.12 .7220

Guerinot, M. L. (2000). The ZIP family of metal transporters. Biochim. Biophys. Acta Biomemb. 1465 190-198. doi: 10.1016/S0005-2736 (00)00138-3

Hacisalihoglu, G., Ozturk, L., Cakmak, I., Welch, R. M., and Kochian, L. (2004). Genotypic variation in common bean in response to zinc deficiency in calcareous soil. Plant Soil 259, 71-83. doi: 10.1023/B:PLSO $0000020941.90028 .2 \mathrm{c}$

Hambidge, M. (2000). Human Zinc deficiency. J. Nutr. 130, 1344S-1349S.

Henriques, R., Jasik, J., Klein, M. Feller, U., Schell, J., Pais, M. S., et al. (2002). Knock-out of Arabidopsis metal transporter gene IRT1 results in iron deficiency accompanied by cell differentiation defects. Plant Mol. Biol. 50, 587-597. doi: 10.1023/A:101994 2200164

Islam, F. M. A., Basford, K. E., Redden, R. J., Gonzalez, A. V., Kroonenberg, P. M., and Beebe, S. (2002). Genetic variability in cultivated common bean beyond the two major gene pools. Genet. Resour. Crop Evol. 49, 271-283.

Jakoby, M., Weisshaar, B., DrögeLaser, W., Vicente-Carbajosa, J., Tiedemann, J., Kroj, T. et al. (2002). bZIP transcription factors in Arabidopsis. Trends Plant Sci. 7, 106-111. doi 10.1016/S1360-1385(01)02223-3

Jiang, W., Struik, P. C., Van Keulen, H., Zhao, M., Jin, L. N., and Stomph, T. J. (2008). Does increased zinc uptake enhance grain zinc mass concentration in rice? Ann. Appl. Biol. 153, 135-147.

Juliano, B. O. (1999). Comparative nutritive value of various staple foods. Food Rev. 15, 399-434. doi: 10.1080/87559129909541197

Larkin, M. A., Blackshields, G., Brown, N. P., Chenna, R., McGettigan, P. A., McWilliam, H., et al. (2007) Clustal W and Clustal X version 2.0. Bioinformatics 23, 2947-2948. doi: 10.1093/bioinformatics/btm404

Li, Z., and Trick, H. N. (2005). Rapid method for high-quality RNA isolation from seed endosperm containing high levels of starch. BioTechniques 38, 872-876.

Lin, Y. F., Liang, H. M., Yang, S. Y., Boch, A., Clemens, S., Chen, C. C., et al. (2009). Arabidopsis IRT3 is a zincregulated and plasma membrane localized zinc/iron transporter. New Phytol. 182, 392-404. doi: 10.1111/j.1469-8137.2009.02766.x

Livak, K. J., and Schmittgen, T. D. (2001). Analysis of relative gene expression data using real-time quantitative $\mathrm{PCR}$ and the 2(T)(-Delta Delta C) method. Methods 25, 402-408. doi: 10.1006/meth.2001.1262

Lopez-Millan, A. F., Ellis, D. R., and Grusak, M. A. (2004). Identification and characterization of several new members of the ZIP family of metal ion transporters in Medicago truncatula. Plant Mol. Biol. 54, 583-596. doi: $10.1023 /$ B:PLAN.0000038271. 96019.aa

Lorieux, M. (2012). MapDisto: fast and efficient computation of genetic linkage maps. Mol. Breed. 30, 1231-1235. doi: 10.1007/s11032-012-9706-y

Milner, M. J., Craft, E., Yamaji, N. Koyama, E., Ma, J., and Kochian, L. V. (2012). Characterization of the high affinity $\mathrm{Zn}$ transporter from Noccaea caerulescens, NcZNT1, and dissection of its promoter for its role in $\mathrm{Zn}$ uptake and hyperaccumulation. New Phytol. 195, 113-123. doi: $\quad 10.1111 /$ j.1469-8137.2012 04144.x

Milner, M. J., Seamon, J., Craft, E., and Kochian, L. V. (2013). Transport properties of members of the ZIP family in plants and their role in $\mathrm{Zn}$ and Mn homeostasis. J. Exp. Bot. 64, 369-381. doi: 10.1093/jxb/ers315

Moreau, S., Rowena, M., Thomson, B. N., Kaiser, B. T., Guerinot, M L., Udvardi, M. K., et al. (2001). GmZIP1 encodes a symbiosisspecific zinc transporter in soybean. J. Biol. Chem. 277, 4738-4746.

Orita, M., Iwahana, H., Hayashi, K., and Sekiya, T. (1989). Detection of polymorphisms of human DNA by gel electrophoresis as SSCPs. Proc. Natl. Acad. Sci. U.S.A. 86, 2766-2770 
Ramesh, S. A., Shin, R., Eide, D. J., and Schachtman, D. P. (2003). Differential metal selectivity and gene expression of two zinc transporters from rice. Plant Physiol. 133, 126-134. doi: 10.104/pp.103.026815

Rastogi, T., and Mathers, C. D. (2002). "Global burden of iron deficiency anaemia in the year 2000," in GBD 2000 Working Paper, World Health Organization (Geneva). Available online at: http://www.who.int/evidence/bod

Ryu, M. S., Guthrie, G. J., Maki, A. B., Aydemir, T. B., and Cousins, R. J. (2012). Proteomic analysis shows the upregulation of erythrocyte dematin in zincrestricted human subjects. Am. J. Clin. Nutr. 95, 1096-1102. doi: 10.3945/ajcn.111.032862

Saltzman, A., Birol, E., Bouis, H. E., Boy, E., De Moura, F. F., Islam, Y., et al. (2013). Biofortification: progress toward a more nourishing future. Glob. Food Secur. 2, 9-17. doi: 10.1016/ j.gfs.2012.12.003

Sandstead, H. H. (1991). Zinc deficiency: a public health problem. Am. J. Dis. Child. 145, 835-859.

Sekara, A., Poniedzialek, M., Giura, J., and Jedrszczyk, E. (2005). Zinc and copper accumulation and distribution in the tissues of nine crops: implications for phytoremediation. Pol. J. Environ. Stud. 14, 829-835.

Shanmugam, V., Lo, J. C., Wu, C. L., Wang, S. L., Lai, C. C., Connolly, E. L., et al. (2011). Differential expression and regulation of ironregulated metal transporters in Arabidopsis halleri and Arabidopsis thaliana - the role in zinc tolerance. New Phytol. 190, 125-137. doi: $\quad$ 10.1111/j.1469-8137.2010. 03606.x

Siddiq, M., and Uebersax, M. A. (2012). "Dry beans and pulses production and consumptionan overview", in Dry Beans and Pulses Production, Processing and Nutrition, eds M. Siddiq and M. A. Uebersax, (Oxford, UK: Blackwell Publishing Ltd.). doi: 10.1002/9781 118448298.ch1

Talke, I. N., Hanikenne, M., and Kramer, U. (2006). Zinc-dependent global transcriptional control, transcriptional deregulation, and higher gene copy number for genes in metal homeostasis of the hyperaccumulator Arabidopsis halleri. Plant Physiol. 142, 148-167. doi: 10.1104/pp.105.076232

Van De Mortel, J. E., Villanueva, A. L., Schat, H., Kwekkeboom, J., Coughlan, S., Moerland, P. D., et al. (2006). Large expression differences in genes for iron and zinc homeostasis, stress response, and lignin biosynthesis distinguish roots of Arabidopsis thaliana and the related metal hyperaccumulator Thlaspi caerulescens. Plant Physiol. 142, 1127-1147.

Wang, S., Basten, C. J., and Zeng, Z. B. (2012). Windows QTL Cartographer 2.5. Department of Statistics, Raleigh, NC: North Carolina State University
Waters, B. M., and Sankaran, R. P (2011). Moving micronutrients from the soil to the seeds: genes and physiological processes from a biofortification perspective. Plant Sci. 180, 562-574. doi: 10.1016/j. plantsci.2010.12.003

Weber, M., Harada, E., Vess, C. Roepenack-Lahaye, E. V., and Clemens, S. (2004). Comparative microarray analysis of Arabidopsis thaliana and Arabidopsis haller roots identifies nicotianamine synthase, a ZIP transporter and other genes as potential metal hyperaccumulation factors. Plant J. 37, 269-281. doi 10.1046/j.1365-313X.2003.01960.x

Wen, K., Seguin, P., St.-Arnaud, M., and Jabaji-Hare, S. (2005). Real time quantitative RT PCR of defense gene transcripts of Rhizoctonia solani infected bean seedlings in response to inoculation with a non pathogenic binucleate Rhizoctonia isolate. Phytopathology 95, 345-353. doi: 10.1094/PHYTO-950345

Wu, J., Zhao, F.-J., Ghandilyan, A. Logoteta, B., Guzman, M., Schat, $\mathrm{H}$., et al. (2009). Identification and functional analysis of two ZIP metal transporters of the hyperaccumulator Thlaspi caerulescens. Plant Soil $325,79-95$

Yang, X., Huang, J., Jiang, Y., and Zhang, H. S. (2009). Cloning and functional identification of two members of the ZIP ( $\mathrm{Zrt}$, Irt-like protein) gene family in rice (Oryza sativa L). Mol.
Biol. Rep. 36, 281-287. doi: 10.1007/s11033-007-9177-0

Zhao, H., and Eide, D. (1996). The yeast ZRT1 gene encodes the zinc transporter of a high affinity uptake system induced by zinc limitation. Proc. Natl. Acad. Sci. U.S.A. 93, 2454-2458. doi 10.1073/pnas.93.6.2454

Conflict of Interest Statement: The authors declare that the research was conducted in the absence of any commercial or financial relationships that could be construed as a potential conflict of interest.

Received: 15 March 2013; accepted: 11 July 2013; published online: 30 July 2013. Citation: Astudillo C, Fernandez AC, Blair MW and Cichy KA (2013) The Phaseolus vulgaris ZIP gene family: identification, characterization, mapping, and gene expression. Front. Plant Sci. 4:286. doi: 10.3389/fpls.2013.00286

This article was submitted to Frontiers in Plant Physiology, a specialty of Frontiers in Plant Science.

Copyright (ㅇ 2013 Astudillo, Fernandez, Blair and Cichy. This is an open-access article distributed under the terms of the Creative Commons Attribution License (CC BY). The use, distribution or reproduction in other forums is permitted, provided the original author(s) or licensor are credited and that the original publication in this journal is cited, in accordance with accepted academic practice. No use, distribution or reproduction is permitted which does not comply with these terms. 